\title{
Misceláned
}

\section{Un sello desde Cádiz para la conmemoración del centenario del títullo de enfermera en España (1915-2015)}

Francisco Herrera Rodríguez ${ }^{1}$, José E. Lasarte Calderay ${ }^{2}$ y Antonio Valiente Bey ${ }^{3}$

${ }^{1}$ Facultad de Enfermería y Fisioterapia (Universidad de Cádiz).

${ }^{2}$ Centro de Salud "La Laguna". Cádiz.

${ }^{3}$ Antonio Valiente Bey (Miembro de la Sociedad Filatélica Gaditana).

Cómo citar este artículo (reseña) en edición digital: Herrera Rodríguez, F., Lasarte Calderay, J.E. y Valiente Bey, A. (2015). Un sello desde Cádiz para la conmemoración del centenario del título de enfermera en España (1915-2015) (Reseña). Cultura de los Cuidados (Edición digital) 19, 41. Disponible en: http://dx.doi.org/10.14198/cuid.2015.41.20>

Correspondencia: (remitirse al correo electrónico)

Correo electrónico: francisco.herrera@uca.es

Recibido: 10/01/2015/ Aceptado: 28/02/2015

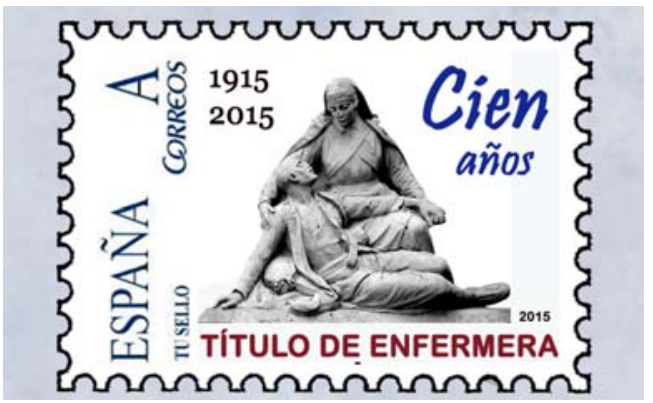

Figura: Tarjeta postal que reproduce un sello conmemorativo del centenario del título de Enfermera en España (19152015). Sello aprobado por Correos (“Tu sello").

La Gaceta de Madrid del día 21 de mayo de 1915 publicó una Real Orden, firmada el día 7 del mismo mes, por Esteban Collantes, Subsecretario del Ministerio de Instrucción Pública y Bellas Artes, de la cual reproducimos un fragmento:

"Vista la instancia presentada por la Congregación de Siervas de María, Ministras de los enfermos, solicitando que se autorice para ejercer la profesión de enfermeras á las religiosas que acrediten tener los conocimientos necesarios con arreglo al Programa que con este fin se establezca, S.M. el Rey (q. D. G.) ha tenido á bien disponer lo siguiente: $1^{\circ}$. Se aprueba el adjunto Programa de los conocimientos necesarios para habilitar de enfermeras á las que lo soliciten pertenecientes ó no á Comunidades religiosas.

$2^{\circ}$. Los conocimientos que el Programa contiene podrán adquirirse previamente, asistiendo para los de carácter práctico á las clínicas, consultorios, asilos ú hospitales que á las aspirantes convengan.

$3^{\circ}$. La prueba de suficiencia consistirá en un examen teórico-práctico ante un Tribunal análogo al que funciona para la reválida de practicantes de la Facultad de Medicina de Madrid, designado por el Decano.

$4^{\circ}$. Las aspirantes aprobadas en estos exámenes obtendrán una certificación expedida por el Decano de la Facultad de Medicina, en la que hará constar que quedan autorizadas para ejercer la profesión de enfermeras.

$5^{\circ}$. Los exámenes se verificarán todos los años en la Facultad de Medicina de la Universidad Central en la fecha que designe el Decanato.

$6^{\circ}$. Las aspirantes á enfermeras satisfarán en la Secretaría de la Facultad para formación de expediente tres pesetas y para pagos de derechos de examen 10 pesetas, con opción á segundo exa- 
men, tres meses después como plazo mínimo, las que no obtuviesen la aprobación en el primero.

De Real orden lo digo á V.I. para su conocimiento y demás efectos. Dios guarde á V.I. muchos años. Madrid, 7 de mayo de 1915 (...).

ESTEBAN COLLANTES.

Señor Subsecretario de este Ministerio"

Por este motivo los arriba firmantes hemos promovido un sello dedicado a la Enfermería en esta efeméride centenaria. A la hora de editar el sello conmemorativo nos hemos encontrado que dentro de los esquemas de "Tu Sello" (Correos y Telégrafos), no se pueden reproducir imágenes de personas que estén vivas. Hemos optado, pues, por diseñar el sello a partir del monumento dedicado a la Duquesa de la Victoria que está en el Parque Genovés de Cádiz. Existe monumento análogo en alguna otra ciudad de España, por ejemplo, Madrid. $\mathrm{Al}$ ver la fotografía con el monumento completo nos dimos cuenta que estábamos homenajeando a la Duquesa de la victoria y que lo que pretendíamos era rendir un homenaje a los orígenes de la enfermería profesional en España, y por eso nos quedamos con el detalle que podéis ver en la imagen. La enfermera y el herido. También nos dimos cuenta que al hacerlo así nos encontramos con una 'Piedad' impresionante, que refleja los desvelos, el trabajo y la dedicación profesional de las enfermeras.

Desde Cádiz queremos contribuir en este Centenario de la legislación del título de Enfermera en España, y al hacerlo somos conscientes de que en esta conmemoración se recoge una tradición de varios siglos cuidando a los enfermos, ya sea desde instancias religiosas o laicas; pero queremos recordar también muy especialmente al cirujano de El Puerto de Santa María (Cádiz), Federico Rubio y Gali (1827-1902), que tanto contribuyó a que esto fuera posible con la fundación en Madrid de la Escuela de Enfermeras de Santa Isabel de Hungría.

Conste nuestro agradecimiento a la Sociedad Filatélica Gaditana que siempre nos apoya en todas nuestras iniciativas filatélicas relacionadas con la Enfermería y la Medicina.

\section{Biblioteca comentada}

\section{AJUSTICIADOS}

Autor: Hernández Conesa, J.

Editorial: Letras de Autor / Año publicación 2014

José Siles González

CEU Facultad Ciencias de la Salud. Universidad de Alicante

Cómo citar este artículo (reseña) en edición digital: Siles

González, J. (2015). Ajusticiados (Reseña). Cultura de los

Cuidados (Edición digital) 19, 41.

Disponible en: http://dx.doi.org/10.14198/cuid.2015.41.19>

Correspondencia:

(remitirse al correo electrónico)

Correo electrónico: jose.siles@ua.es.

Recibido: 10/11/2014/ Aceptado: 27/12/2014
AJUSTICIADOS

JuAna HeRnández Conesa

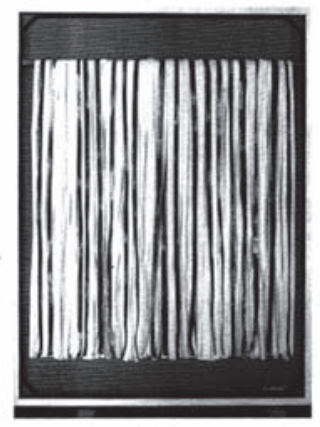

(C) 